\title{
THE RESPONSIBILITY OF THE YOUTH \\ FOR ASSUMING AND CONFESSING THE \\ CHRISTIAN IDENTITY \\ IN THE CONTEXT OF SECULARISATION \\ CHALLENGES
}

Alexandru Mălureanu*

Abstract: This paper tries to emphasize the importance and the responsibility of the Youth for assuming and confessing the Christian identity in the context of the challenges of secularization and globalisation. In our world characterized by pluralism and multiculturalism we have to realize the importance of interpersonal relationship in the perspective of communication and communion. Dialogue plays a fundamental role in the era of communication. Dialogue means confession. In the mentioned context, dialogue can be understood also as a Christian confession. In the context of the year 2016, declared in the Romanian Patriarchate as Solemn year of Religious Education of the Christian Orthodox Youth, is useful to analyze some aspects regarding the beauty of youthfulness and the sanctity of life.

Keywords: Youth, responsibility, identity, communication, communion, secularization, globalization

\section{Introduction}

In this paper I will try to emphasize the importance, but also the responsibility of the Youth for assuming and confessing the Christian identity in the context of our World. This paper is structured in two parts: in the first part I will present the challenges of secularization and the perspectives of interpersonal communication and in the second part I will analyze some aspects of the beauty of youthfulness and the holiness of life.

*PhD, Faculty of Orthodox Theology Justinian Patriarhul, University of Bucharest; Inspector at the Department for Theological Education, Romanian Patriarchate. 


\section{The challenges of secularization and the perspectives of interpersonal communication}

In the actual context of secularization and globalization, certain challenges arose, such as: relativisation of Christian values, ignorance, carelessness towards the sacred, living without God, the removal of spiritual dimension from the public space, the tendency to individualize of the modern man, spiritual crisis, religious syncretism.

Globalization produces the destructive effects on spirituality, as long as the laicity of life is emphasized; atheist, nihilistic, secularist currents appear or New Age kind of products arose that makes a god out of the postmodern superman ${ }^{1}$.

Anthropocentrism had three unexpected consequences:

"'desecration of the man and world', as a tendency to bring the profane under the authority of the sacred. Desecration, on the other hand, started the process of world secularization. Through this process, the progressive removal of religion from the social and cultural life is being tried. Secularization, on the other hand, causes global ecological crisis as a result of man's tendency to take God's place on Earth and to consider nature as a property which he can exploit it irresponsibly". ${ }^{2}$

Secularization and its direct result, the ecological crisis, were followed by a dramatic spiritual backsliding, which resulted in interior destabilization of the $\operatorname{man}^{3}$.

The basis underlying all contemporary human crisis is the spiritual crisis.

${ }^{1}$ David Pestroiu, Ecumenismul - intre susţinere şi contestare, in: „Revista Teologică”, New Series, Year XVII, No. 3, July-September, 2007, p. 323.

2 Sterea Tache, Dumnezeu, omul şi creaţia în teologia ortodoxă şi $\hat{\imath}$ preocupările ecumenismului contemporan, in: „Ortodoxia”, Year XLIX, No. 34, July-December, 1998, p. 129.

${ }^{3}$ Idem, Secularizarea şi crizele contemporane, in: „Sudii Teologice”, II-nd Series, Year LV, No. 3-4, July-December, 2003, p. 24. 
"Living in the postmodern reality it's assumed that the source of economical crisis in which specific consumerist life in the era of globalization is floundering, is the spiritual crisis ... Life demonstrates that the boundless will of wellness and comfort, specific to the contemporary man, inevitably attracts egocentric individualism, which followed by personal interest, closes the enlightening, dynamic and creative perspective of the human spirit"4.

The contemporary man must try to understand the intentionality that exists in human being for communication and interpersonal communion.

"The naturalness of human solidarity represents an existential gift meant to provide true communication and communion amongst men... Thus, when the Holy Scripture tells us that 'God saw that's not good that the man should be alone', we must understand that God, the Creator of man, implanted social zones in his conscience in order to be a 'social being', which means that inside the human being the intentionality towards communication and communion is written down as a natural law, which urgently must be respected if he wants to fulfil its destiny in the world... Isolation or marginalisation without hope, being improper to the human nature, close the natural aspirations of the human spirit... Interpersonal dialogue can confirm its authenticity as dynamic and creative reciprocity when we manage to overcome personal interests selfishness"

The man fulfils himself in communication and communion with his fellows and God because

"the man, as a being of communication cannot live in solitude. Communion can only be achieved between persons. The person is a spiritual being with values that tends to participate in the world of values through communion. Each person is a unity that manifests his unique specific amongst other persons. This uniqueness of person doesn't mean isolation, on the contrary, the person always tends towards communion. Within the communion with God doesn't mean

${ }^{4}$ Sorin Cosma, Solidaritatea umană şi comunicarea prin cuvânt, in: „Altarul Banatului”, New Series, Year XXIII, No. 1-3, January-March, 2012, p. 18.

${ }^{5}$ Ibidem, p. 18-19. 
that he did something through a strict personal endeavor, but through the gift of God through which it enters in another plan of existence ... we meet God through the grace that works within us" ${ }^{\text {" }}$.

Towards the actual challenges, the affirmation of Orthodox identity is imposed with necessity

"as a unifying religious system of all human existence in Christ and achieving the state of communion as a reply towards singular expression. Thus, through social, ecological, missionary programmes, through pilgrimages, cultural actions, youth events, by valuing the resources of the internet and media, the Church could reach the souls of those who are willing for communion"".

The return to Christian authentic values is the most efficient solution that could place the man normally with the environment, his fellows and himself ${ }^{8}$.

In this pluralist context, we must realize the importance of human relationships in the perspective of reasoning and accepting the cultural and religious diversity. Interpersonal communication represents a priority and a necessity in today's multicultural and multireligious society. Thus, the dialogue is an integrating part of relationship between people of different faith that participate in the community life 9 .

Dialogue is a spiritual state, an attitude of love and respect towards fellows of other faiths. It sees the partners as persons

6 Gheorghe Holbea, Teologia Cuvântului, Course Support, Master of Communication and Communion, The „Justinian Patriarhul Faculty of Orthodox Theology", The University of Bucharest Publishing House, 2013, p. 48.

7 David Pestroiu, Misiunea Bisericii Ortodoxe în postmodernitate, în „Theologia Pontica”, Constanța, Year II, No. 1, 2009, p. 130-145.

${ }^{8}$ Sterea Tache, Secularizarea şi crizele contemporane, p. 27.

${ }^{9}$ S. J. Samartha, Courage of Dialogue, Ecumenical Issues in inter-religious relationship, Geneva, World Council of Churches (WCC), 1981, p. 1 apud. Nicolae Achimescu, Noile mişcări religioase, Cluj-Napoca, Limes Publishing House, 2004, p. 304. 
instead of simple statistics, it doesn't avoid controversies and doesn't only emphasize the common goals, openly recognizing the existing difficulties among human relationships ${ }^{10}$.

Dialogue means testimony, thus, the dialogue can even be seen as a Christian testimony. Thus, the opening towards communication with those of other faiths represents an expression of Christian confession nowadays ${ }^{11}$, dialogue through which Christ is revealing Himself to those who didn't met Him ${ }^{12}$.

Dialogue as a testimony assumes love. In this context, the young people have a great responsibility to be aware that their testimony about the Truth and Love must be a testimony in dialogue, just like God's testimony for the people, a testimony of love where God is permanently calling us ${ }^{13}$.

The Orthodox Church must get involved in eccumenical dialogues in order to firmly express its fidelity for the Truth, for a dogma that's not a subject of syncretistic negotiations. Thus, it has the duty of being confessing through love and patience. Pluralism could be a challenge for the Church, but it forces it to accept dialogue and thus to firmly combat counter-testimony (proselytism) ${ }^{14}$.

Given these facts, those who study theology have the duty to understand that it is fundamentally confessing

"not in the cheap way of ideological propaganda, but as a friendly opening based on the redeeming grace addressed to those who are craving for the Kingdom of Heaven, consciously or not. This confession, started with the Apostles, direct disciples of Christ, is

\footnotetext{
${ }^{10}$ Nicolae Achimescu, op. cit., p. 305.

${ }^{11}$ Ibidem.

12 *** The Uppsala Report, Bz. N. Goodall (ed.), Geneva, WCC, 1968, p. 29, apud. Nicolae Achimescu, op. cit., p. 306.

${ }^{13}$ Nicolae Achimescu, op. cit., p. 306.

${ }^{14}$ David Pestroiu, art. cit., p. 130-145.
} 
continued till today by the Church of which fundamental mission is that of opening a new reality brought to the world by Jesus Christ"15.

Therefore, Theology assumes existential confession of God. Authentic theological communication overcomes both the common language but also stereotypes and cliches.

In real society, communication takes to communion; communication also being

"an expression of communion, that means more than just a simple information. In communication the word is not only information, but signifies the presence of the person in the spoken words that can be converted into acts with power of life. Not the information is important, but the overwhelming presence of the person in the word makes the communication more authentic. A real communication is achieved when we are present in what we say, authority of the word being achieved when there is neither exteriority nor divergence between what we say and what we live. If today a crisis of communication exists, a depreciation of word, it's because of the lack of life, of our own speech substance. The living, edifying word was converted in false speech, the spiritual power of the word is lost in the search of crafted and pompous forms of speeches that became cliches without any impact to the life of those who listen to it" $"$.

The achieving of communication with our fellows is motivated and boosted by the communion with God who, restoring our spiritual being, makes from communication a law of human solidarity ... Today's man, due to its disarray, can no longer find himself in the order of natural dialogue: 'God-man-world', but it loses himself in the absurd noise of existence ${ }^{17}$.

The spoken word must be applied in real life,

${ }^{15}$ Răzvan Andrei Ionescu, Adrian Nicolae Lemeni, Teologie ortodoxă şi ştiinţă. Repere pentru dialog, Bucharest, The Biblical and Missionary Institute of the Romanian Orthodox Church Publishing House, 2007, p. 29.

16 Adrian Lemeni, Aspecte apologetice contemporane, Bucharest, ASAB Publishing House, 2010, p. 67.

${ }^{17}$ Sorin Cosma, art. cit., p. 20. 
"during the dialogue, one must ask for the meaning of the word that's being addressed, harmonized with the capacity of giving the right answer... The deed that's complying to the word must be added, meaning that the word must always be harmonically tied of the deed. Harmonized by the deed, verbal communication receives creative powers, offering to the human solidarity the necessary force for its optimum affirmation in human life. Thus, only in this harmony, verbal communication would show its authentic and full glow that perfects human mission in the world, as the son of God, united with his fellows and the whole creation" $"$.

The contemporary lack of sense can only be fixed by referring to Christ, the Doctor of souls and bodies of human being from all times and places. Only faith in Christ that is saving the man and opens his path towards communion with God; it pulls the contemporary man out of sense and identity crisis in which he is stuck. Christ brings the man back in himself, it makes him responsible to others by offering him the eternal life. ${ }^{19}$

In an individualistic society, the need for spiritual communion between men and search for permanent and profound spiritual values is sensed ${ }^{20}$.

By belonging to Christ's Church we have the certitude of communication and communion with God.

"One of the contemporary world paradoxes is that once with the wave of society globalization and secularization, the need for spirituality arises. Sometimes this search is disconnected from the current life and throws itself into personal experiences lived through ideas and exotic spiritual currents. Christian spirituality is personalistic, but also it has a strong communitarian dimension being a continuous communication with our fellows ... A spirituality of communion knows various

${ }^{18}$ Ibidem, p. 35 .

19 Adrian Ioniță, Hristologia neopatristică în gândirea părintelui Dumitru Stăniloae (PhD Paper), Bucharest, The University of Bucharest Publishing House, 2010, p. 45.

20 Daniel, Patriarhul Bisericii Ortodoxe Române, Misiune prin imagine şi cuvânt, in: „Misiune pentru mântuire. Lucrarea Bisericii în societate”, Bucharest, Basilica Publishing House, 2009, p. 535. 
expressions, but it can be related to the foundations of our faith in God and our Church membership, the mystical body of Christ" ${ }^{21}$.

The Church has a social and communitarian vocation, being permanently connected to the realities that the man's confronting with.

"The communion with the resurrected Christ is done through grace but also the Church heralds to the world salvation in Christ through grace ... In the Church we are living the fervent of eternal life under the protection of Theotokos and of saints of all times, by participating in divine services, living a pure life, through the beauty of the sanctuaries and the happiness of solidarity in philanthropy ... The vocation and mission of the Church is to pass the Holy Grace to the world and create solidarity among people; these are essential for a 'communication spirituality'."22

Thus, communication also has a powerful missionary dimension:

"in a Christian point of view, the contents of communication is Christ and his Gospel. Thus, communication becomes mission because it is not sending an ideology and doesn't have the purpose to penetrate consumerist society logic, but it follows the word of Holy Apostle Paul: 'For we preach not ourselves, but Jesus Christ the Lord' (2 Cor. 4:5). The fundamental values of Christian communication are: the truth of faith and reality of creation, sanctity of life, person dignity and integrity, responsibility for content and purpose of communication." ${ }^{23}$

Man's purpose is not of empowerment and alienation, but to

"transfigure and strengthen the relationship of communication and communion with God and fellows: The Holy Trinity as supreme

21 Nicolae Dascălu, Comunicatorul creştin şi vocaţia lui de a fi sarea pământului, in: „Studii Teologice”, III-rd Series, Year VI, No. 4, OctoberDecember, 2010, p. 40-41.

${ }^{22}$ Ibidem, p. 40.

${ }^{23}$ Ibidem, p. 47. 
communion is not confused with creation, but it is present in the creation through uncreated energies. Thus, the man, through the Church must contribute to the transfiguration of creation in Christ through the Holy Spirit. 'God's presence in the creation, its transfiguration in Christ and in Church through the Holy Spirit, represents the Orthodox answer to the process of world secularization'. The man wasn't created for secularization and autonomy towards God, but for transfiguration and communion with God"24.

\section{The beauty of youthfulness and the holiness of life}

After this brief analysis of secularization challenges and interpersonal communication perspectives, I will present a few aspects referring to the role and mission of the youth in the life of Church.

During the year 2016 declared in the Romanian Patriarchate as Solemn year of Religious Education of the Christian Orthodox Youth it is important to mention that the youth represent the hope of Church's mission. Family, Church and School are essential in forming new generations, understanding the responsibility of cooperation in order to valorize an education of quality.

The youth period is delicate but also beautiful. All of us wish to remain young. But a blessing youth can be lived only with the help of Christ, the perfect model of eternal youth.

God loves the youth! Christ the Saviour loves the youth that worships God, He Himself being obedient in His youth grew in wisdom and stature, and in favor with God and man (Luke 2: 52). Christ promises salvation to those with a pure heart, appreciating St. John the Apostle's youth, whom by his bodily and spiritual purity demonstrated that honest youths are pleasing God. The Son of God demonstrated fatherly kindness to the youth by resurrecting youths: Iair's daughter and the son of widow from Nain. Still, He gave the best advice to the rich young man that wanted to earn eternal life.

24 Sterea Tache, Dumnezeu, omul şi creaţia în teologia ortodoxă şi $\hat{\imath}$ preocupările ecumenismului contemporan, p. 158. 
During the history of salvation, many youths have proven themselves: St. Paul, apostle of the Gentiles, started his mission as young; St. Stephanos, the first archdeacon, was an ardent young man, an example of dedication for Christ but also of forgiveness to those who murdered him. St. Basil the Great and St. Gregory the Theologian were stating that in their youth, they only knew two paths: one of the Church and the other of the school and one ideal: virtue.

True examples of young Christians enlightened Church's path in different ways: as studious youths, young parents of good Christian families, as youths that were separated from the world and that were living only for and with Christ.

During the persecutions, many youths became martyrs for Christ. Also in the Romanian nation we have the example of St. Voivode Martyr Constantin Brancoveanu's four children: Constantin, Stefan, Radu and Matei which defended their ancestral faith even with the price of life ${ }^{25}$.

During the communist period, many youths kept their faith even in jails (for example Valeriu Gafencu, entitled The saint of jails). Even in our days, many youths from some Arabian countries are being martyred for the simple fact that they are Christians. All these youths are now heroes and saints that acquired what they fervently wanted: eternal worship of Christ in an everlasting life.

We, today's youngsters, have a great responsibility: to seek real values and models instead of non-values, deceiving and temporary idols. True values form powerful conscience and personalities that will be capable of having a well argumented point of view in discussions with others, but in the same time, it will have the courage of faith and the courage to confess Christ. In order to be good confessors, the youths must try and maintain a living and natural language and they must live what they preach!

${ }^{25}$ Mircea Păcurariu, Hristos şi tineretul în trecut şi azi. Cuvânt de învăţătură către tineri, in: „Revista Teologică”, New Series, Year VII (79), No. 3, JulySeptember, 1997, p. 172-175. 
There is a temptation for theologians: to assume theological knowledge without any real implication, without practicing what they have learned. So a discrepancy appears between word and act, between what they say and what they do. In the Church it is essential to be authentic, honest and vertical.

A wise word says that we are a small part of every person that we meet in our life. That is why it is important to try and find good parts in people that we meet. We have something to learn from every person, even from those that we don't even expect. Another good and motivating motto is this: Give yourself to overcome yourself! (how Fr. Teofil Paraian used to say). In other words, being involved body and spirit in what you do, and seriosity and consistency will help you to advance and to form yourself.

I think it is very important for the youths to follow their souls, to try and discover their vocation, what they sense that would fulfill them spiritually? To answer these existential questions, we must get right answers from the right people, because, even during youth, good guidance from spiritual fathers and natural parents but also from teachers that are more close to the youths is required. God speaks through people like the confessor, parents and mentors, guiding us so beautiful and real that you can effectively feel His providence and the fact that $\mathrm{He}$ has a plan with each of us.

Youths must ask for advice in life to receive God's blessing as a reward for searching and listening to His guidance through people they care for. During the age of intellectual and spiritual development, permanent consultation is fundamental, that is why I encourage the youths to ask, search and especially I wish them to find answers to their questions that is bugging them spiritually.

I recommend all the youths to apply for abroad scholarships. They will witness a unique experience that is going to enrich them both intellectually and spiritually, living a real life lesson. The contact with another environment, another context, with people of other confessions and religions could open new horizons for them and it could help them to see the world from another angle. 
The Romanian Patriarchate ${ }^{26}$ runs a number of programmes for the youths, understanding the importance of forming them for life. Besides encouraging diligent youths to study abroad, the Romanian Orthodox Church contributes and assures keeping Religion in schools (by exemplary involving and mobilization awarded with the trust of $92 \%$ of people who wish to know and keep traditions and faith in God, shortly, the identity of Romanian nation).

In the same time it offers the possibility of continuing to study Religion in university and pre-university from the whole country: in 29 theological Seminaries, in 11 faculties and in 4 departments of Orthodox theology. Many youths that studied Religion convinced their parents of the beauty of the faith, thus becoming little apostles in their families. I would then mention the programmes: Alege Școala! - Choose the School! (focused on encouraging and helping youths that come from poor families to continue their studies), Hristos împărtăşit copiilor - Christ communicated to the children (and to the youths), contests of church music (Lăudați pe Domnul! - Praise the Lord!), of painting (Icoana ortodoxă - lumina credinței - Orthodox Icon - the light of the faith), but also the program Calea mântuirii (The Way), initiated by the professors from the Orthodox Institute for Christian Studies from Cambridge where the youths can involve in the parishes where they belong, in order to establish some meetings with the believers and with the help of special guests, to watch theme movies and after this to divide in discussion groups. These can become real interesting spiritual meetings. Thus, I would remind the Church associations of youths, Asociația Studenților Creștin-Ortodocși Români (A.S.C.O.R.) - The Association of Romanian Orthodox Christian Students and Liga Tinerilor Creștin-Ortodocși Români (L.T.C.O.R.) - The League of Romanian Orthodox Youth. These two organisations of youths are the most important from the Romanian Orthodox Church. By their activities achieved (through they emphasize the important moments of Church and civil year) demonstrate that they are active members of the Church.

${ }^{26} \mathrm{http}: / /$ www.patriarhia.ro (Accessed on 3 April 2016). 
This autumn, in the capital, the International Meeting of Orthodox Youth will take place where youths from abroad and from Romania will participate, being a good opportunity to assume a spiritual living in communion and show unity, communication and cooperation.

Even if today being faithful means to assume a liturgical and ecclesial life and being criticised by some persons less present in Church life, doesn't mean that youths must be intimidated, scared or unconfident. In today's world, the majority is being discriminated, but we must understand and confess that we are the majority, not the little humanitarian groups, secularists and atheists formed of 2 or 3 individuals. The true victory against actual secularization is that of the youths and parents that chose with their souls, so that God would be present in Romanian public schools.

The Church trusts the youths, supporting them as a spiritual mother that is always thriving to form them as future saints ! Thus, the youths have the responsibility to pray and discuss with people they trust, to be dedicated in what they do by being active, organized, open-minded, thankful and prepared for ministry so that whenever God will need them, they should be ready!

\section{Conclusions}

To sum up I will present the conclusions of this paper. In our world characterized by globalisation, pluralism and multiculturalism we have to realize the importance of communication. Dialogue plays a fundamental role in the era of communication. Dialogue could also be seen as confession. In the current context of secularization, the youths have a confessing responsibility to assume and proclaim Christian identity, emphasizing the importance of interpersonal relationships in the perspective of communication and divine-human communion. 


\section{References}

1. Achimescu, Nicolae, Noile mişcări religioase, Cluj-Napoca, Limes Publishing House, 2004.

2. Cosma, Sorin, Solidaritatea umană şi comunicarea prin cuvânt, in: „Altarul Banatului”, New Series, Year XXIII, No. 1-3, January-March, 2012.

3. Daniel, Patriarhul Bisericii Ortodoxe Române, Misiune prin imagine şi cuvânt, in: „Misiune pentru mântuire. Lucrarea Bisericii în societate”, Bucharest, Basilica Publishing House, 2009.

4. Dascălu, Nicolae, Comunicatorul creştin şi vocaţia lui de a fi sarea pământului, in: „Studii Teologice”, III-rd Series, Year VI, No. 4, OctoberDecember, 2010.

5. Holbea, Gheorghe, Teologia Cuvântului, Course Support, Master of Communication and Communion, The „Justinian Patriarhul Faculty of Orthodox Theology", The University of Bucharest Publishing House, 2013.

6. Ionescu, Răzvan Andrei, Lemeni, Adrian Nicolae, Teologie ortodoxă şi sstiinţă. Repere pentru dialog, Bucharest, The Biblical and Missionary Institute of the Romanian Orthodox Church Publishing House, 2007.

7. Ioniță, Adrian, Hristologia neopatristică în gândirea părintelui Dumitru Stăniloae (PhD Paper), Bucharest, The University of Bucharest Publishing House, 2010.

8. Lemeni, Adrian, Aspecte apologetice contemporane, Bucharest, ASAB Publishing House, 2010.

9. Păcurariu, Mircea, Hristos şi tineretul în trecut şi azi. Cuvânt de învăţătură către tineri, in: „Revista Teologică”, New Series, Year VII (79), No. 3, July-September, 1997, p. 172-175.

10. Pestroiu, David, Ecumenismul - între susţinere şi contestare, in: „Revista Teologică”, New Series, Year XVII, No. 3, July-September, 2007.

11. Pestroiu, David, Misiunea Bisericii Ortodoxe in postmodernitate, in: „Theologia Pontica”, Constanţa, Year II, 2009, No. 1.

12. Tache, Sterea, Dumnezeu, omul şi creaţia în teologia ortodoxă şi în preocupările ecumenismului contemporan, in: „Ortodoxia”,Year XLIX, No. 34, July-December, 1998.

13. Tache, Sterea, Secularizarea şi crizele contemporane, în „Sudii Teologice", II-nd Series, Year LV, No. 3-4, July-December, 2003. 